TITLE:

\title{
Evaluation of drinking water intake, feed water intake and total water intake in dry and lactating cows fed silages
}

$\operatorname{AUTHOR}(S)$ :

Kume, S.; Nonaka, K.; Oshita, T.; Kozakai, T.

\section{CITATION:}

Kume, S....[et al]. Evaluation of drinking water intake, feed water intake and total water intake in dry and lactating cows fed silages. Livestock Science 2010, 128(1-3): $46-51$

ISSUE DATE:

2010-03

URL:

http://hdl.handle.net/2433/102278

\section{RIGHT:}

c 2009 Elsevier B.V. All rights reserved.; この論文は出版社版でありませ ん。引用の際には出版社版をご確認ご利用ください。; This is not the published version. Please cite only the published version. 
WATER INTAKE IN DAIRY COWS

\title{
Evaluation of drinking water intake, feed water intake and total water intake in dry and lactating cows fed silages
}

\author{
S. Kume ${ }^{\text {a, }}$, K. Nonaka ${ }^{\text {b }}$, T. Oshita ${ }^{c}$, and T. Kozakai ${ }^{c}$ \\ ${ }^{a}$ Graduate School of Agriculture, Kyoto University, Kyoto 606-8502, Japan \\ b Natl. Inst. Livestock and Grassland Sci., Nishinasuno 329-2793, Japan \\ c Natl. Agric.Res.Cent. for Hokkaido Reg., Sapporo 062-8555, Japan
}

ABSTRACT: Data of 46 water balance measurements were collected from dry and lactating Holstein cows in the controlled climatic chamber, which maintained at $20^{\circ} \mathrm{C}$ and $60 \%$ relative humidity, to evaluate between drinking water intake (DWI), feed water intake (FWI), total water intake (TWI) and some variables in cows. Orchardgrass silage, alfalfa silage and corn silage were offered in dry cows, and alfalfa or orchardgrass silage and concentrates were given as a TMR in ratio of 60:40 in lactating cows. DMI and milk production were highly related to DWI and TWI of lactating cows. DWI in dry and lactating cows increased and FWI decreased as dietary DM increased, but there was a very weak correlation between dietary DM and TWI. In both dry and lactating cows, positive correlations were obtained between dietary CP or K and TWI, especially highly correlations between dietary K and TWI. There were strong positive correlations between $\mathrm{N}$ intake, $\mathrm{K}$ intake or urine volume and TWI rather than DWI in dry and lactating cows. These results suggest that dry and lactating cows accelerate DWI to excrete large amounts of $\mathrm{K}$ or $\mathrm{N}$ into urine in excess of their needs, but

\footnotetext{
* Corresponding author. Tel: +81-75-7536325. Fax: +81-75-7536345. 
TWI is more suitable to evaluate the effects of dietary $\mathrm{CP}$ or $\mathrm{K}$ on water intake and urine volume in dairy cows.

Key Words : dry cows, lactating cows, nitrogen, potassium, urine volume, water intake

\section{INTRODUCTION}

Water is the most important nutrient for dairy cows. The sum of drinking water intake (DWI) and ingestion of water contained in feed (FWI) is the total water intake (TWI), because metabolic water is an insignificant source compared with DWI and FWI (NRC, 2001). High producing cows require large amounts of water as well as appropriate amounts of energy, protein and minerals to support high milk yield. The importance of high quality roughage, especially high quality silages such as alfalfa and corn silage, has been recognized for maximal milk yield, and silage is an important water source for dairy cows.

Loss of water from the body occurs through milk production, urine and fecal excretion, sweat and vapor loss from lungs (NRC, 2001). A sufficient supply of water is essential to avoid negative effects on animal health, performance and welfare (Murphy, 1992; Meyer et al., 2004), and 25 and 50\% restriction of drinking water relative to ad libitum intake decreased feed intake and milk yield in dairy cows (Steiger Burgos et al., 2001). However, a surplus supply of water may lead to disturb a constant extracellular fluid volume and osmolality and increase urine volume in dairy cows. The decreasing urine production from dairy cows is needed for the optimum cow management in dairy farms, because environmental pollution from livestock wastes has a serious problem in Japanese dairy farming. Urinary water excretion was positively related to water availability, amount of water absorbed from the intestinal tract and urinary $\mathrm{N}$ and $\mathrm{K}$ excretion in cows (Murphy, 1992). In the previous paper (Kume et al., 2008a), the urine volume in cows increased with the increasing urinary excretion of $\mathrm{K}$ and $\mathrm{N}$, and the increase of urine production may be due to the maintenance of 
urine or plasma osmolality. Although the optimal control of water intake in dairy cows is useful for decreasing urine production and maintaining high milk production, few reports have been demonstrated the relationships between water intake, dietary nutrient contents, nutrient intake and urine production, respectively.

The objective of this study was conducted to clarify the relationships between TWI, DWI, FWI and some variables such as nutrient contents, nutrient intake and urine production in dry and lactating cows in the controlled climatic chamber, which maintained at $20^{\circ} \mathrm{C}$ and $60 \%$ relative humidity.

\section{MATERIAL AND METHODS}

This research was approved by the guide for the care and use of animals in National Agricultural Research Center for Hokkaido Region. The experiment was conducted as previously described (Kume et al., 2004, 2008a, 2008b; Kojima et al., 2005). Data of 30 and 16 balance measurements were collected from dry and lactating Holstein cows, respectively. Orchardgrass silage, alfalfa silage, corn silage, orchardgrass plus alfalfa silage, orchardgrass plus corn silage or alfalfa plus corn silage were offered to meet the TDN requirements of dry cows (Agriculture, Forestry, and Fisheries Research Council Secretariat, 1994). Because of the low CP contents, $9 \%$ of soybean meal was supplemented for the dry cows fed corn silage. In 8 lactating cows, orchardgrass silage or alfalfa silage diets were offered in the switch back trials. Roughage and concentrates were given as a TMR in ratio of 60:40 to meet the TDN requirements of the cows.

The trials were performed for 14 days in dry and lactating cows after an initial adaptation period of 5 to 7 days. The cows were fed equal amounts of feed at 08:00 and 16:00 h and were given free access to water. The lactating cows were milked twice daily, and milk weights were recorded. Cows were housed in the individual pens for 7 to 10 days during the 

feed adjustment period, followed by the 4 to 7 day collection period from 10:30 to 10:30 $\mathrm{h}$ daily in the metabolic chamber. The metabolic chamber was maintained at $20^{\circ} \mathrm{C}$ and $60 \%$ relative humidity. Feed refusals and drinking water intake were recorded daily, and drinking water intake was measured by the water meter. Feces and urine from each cow were separately collected and weighed daily during the collection period.

Samples of feces, feed and feed refusals were oven-dried for 48 hours at $60^{\circ} \mathrm{C}$ and ground to pass a 1-mm screen. The DM contents of feces, feed and feed refusals were determined by oven drying at $100^{\circ} \mathrm{C}$ for 2 hours, and then water intake from feed and fecal water excretion in each cow were calculated. The CP, ADF, NDF and K contents of feces, feed and feed refusals were determined as previously described (Kume et al., 2001).

Relationships between TWI, DWI, FWI and other variables in dry and lactating cows were examined by correlation and regression analyses of SAS (1997). Significance was declared at $P<0.05$.

\section{RESULTS}

Mean TWI in dry cows was $30.3 \mathrm{~kg} /$ day, consisted of $16.0 \mathrm{~kg}$ (52.8\% of TWI) from DWI and $14.3 \mathrm{~kg}$ (47.2\% of TWI) from FWI, whereas mean TWI in lactating cows was $98.4 \mathrm{~kg} / \mathrm{day}$, consisted of 77.6kg (78.9\% of TWI) of DWI and 20.8kg (21.1\% of TWI) from FWI (Tables 1 and 2). Mean urine volume and fecal water excretion in dry cows were 12.8 and $12.4 \mathrm{~kg} / \mathrm{day}$, respectively, and those in lactating cows were 21.9 and $35.2 \mathrm{~kg} /$ day, respectively. Mean milk yield in lactating cows was $29.5 \mathrm{~kg} /$ day, ranging from 21.9 to $35.3 \mathrm{~kg} /$ day. Nutrient contents and nutrient intake in dry and lactating cows varied.

In dry cows, dietary DM (P<0.05), CP (P<0.001), ADF $(P<0.001)$, $(P<0.001)$, DMI $(P<0.001)$, N intake $(P<0.001)$, ADF intake $(P<0.001)$, NDF intake $(P<0.01)$, K intake ( $P<0.001)$, urine volume $(P<0.001)$, fecal water $(P<0.001)$ and DWI $(P<0.001)$ were 
positively correlated to TWI, but FWI $(P<0.001)$ was negatively correlated to TWI. Dietary DM ( $P<0.001)$, CP $(P<0.01), \mathrm{K}(P<0.001)$, N intake $(P<0.01)$, K intake $(P<0.001)$ and urine volume $(P<0.001)$ were positively correlated to DWI. Dietary ADF $(P<0.05)$, NDF $(P<0.01)$, ADF intake $(P<0.01)$, NDF intake $(P<0.01)$ and BW $(P<0.01)$ were positively correlated to FWI, but dietary DM $(P<0.001)$ and $\mathrm{K}(P<0.05)$ were negatively correlated to FWI.

In lactating cows, Dietary DM (P<0.05), CP ( $P<0.05)$, K $(P<0.001)$, DMI $(P<0.001)$, N intake $(P<0.001)$, ADF intake $(P<0.01)$, K intake $(P<0.001)$, milk yield $(P<0.01)$, urine volume $(P<0.001)$ and DWI $(P<0.001)$ were positively correlated to TWI, but dietary NDF $(P<0.01)$ was negatively correlated to TWI. Dietary DM $(P<0.001), \mathrm{K}(P<0.05)$, DMI ( $P<0.001)$, N intake $(P<0.01)$, ADF intake $(P<0.01)$, K intake $(P<0.001)$, milk yield $(P<0.01)$ and urine volume $(P<0.01)$ were positively correlated to DWI, but dietary NDF $(P<0.05)$ was negatively correlated to DWI. Only dietary DM $(P<0.001)$ was negatively correlated to FWI.

There were strong correlations between dietary DM and DWI or FWI in dry and lactating cows, but a weak correlation was obtained between dietary DM and TWI (Figure1). The regression equations of dietary DM $\left(\mathrm{X}_{\mathrm{DM}}\right)$ on DWI in dry cows $\left(\mathrm{Y}_{\mathrm{DDW}}\right)$, FWI in dry cows ( $\left.\mathrm{Y}_{\mathrm{DFW}}\right)$, DWI in lactating cows $\left(\mathrm{Y}_{\mathrm{LDW}}\right)$ and FWI in lactating cows $\left(\mathrm{Y}_{\mathrm{LFW}}\right)$ were as follows.

$$
\begin{aligned}
& \mathrm{Y}_{\mathrm{DDW}}=0.915( \pm 0.119)^{* * *} \mathrm{X}_{\mathrm{DM}}-18.8( \pm 4.7)^{* * *} \quad\left(R^{2}=0.67,{ }^{* * *} P<0.001\right) \\
& \mathrm{Y}_{\mathrm{DFW}}=-0.572( \pm 0.056)^{* * *} \mathrm{X}_{\mathrm{DM}}+36.1( \pm 2.2)^{* * *}\left(R^{2}=0.78,{ }^{* * *} P<0.001\right) \\
& \mathrm{Y}_{\mathrm{LDW}}=1.58( \pm 0.29)^{* * *} \mathrm{X}_{\mathrm{DM}}-3.4( \pm 14.9) \quad\left(R^{2}=0.66,{ }^{* * *} P<0.001\right) \\
& \mathrm{Y}_{\mathrm{LFW}}=-0.764( \pm 0.078)^{* * *} \mathrm{X}_{\mathrm{DM}}+59.9( \pm 4.1)^{* * *} \quad\left(R^{2}=0.86,{ }^{* * *} P<0.001\right)
\end{aligned}
$$

There were strong correlations between dietary K or CP and TWI in dry cows, and there were positive relationship between dietary K or CP and TWI in lactating cows (Figure 2). The regression equations of dietary $\mathrm{K}\left(\mathrm{X}_{\mathrm{K}}\right)$ on TWI in dry cows $\left(\mathrm{Y}_{\mathrm{DTW}}\right)$ and TWI in lactating cows ( $\left.\mathrm{Y}_{\mathrm{LTW}}\right)$ and dietary $\mathrm{CP}\left(\mathrm{X}_{\mathrm{CP}}\right)$ on TWI in dry cows $\left(\mathrm{Y}_{\mathrm{DTW}}\right)$ and TWI in lactating cows $\left(\mathrm{Y}_{\mathrm{LTW}}\right)$ were as follows. 


$$
\begin{aligned}
& \mathrm{Y}_{\text {DTW }}=7.43( \pm .1 .27)^{* * *} \mathrm{X}_{\mathrm{K}}+12.8( \pm 3.2)^{* * *}\left(R^{2}=0.53,{ }^{* * *} P<0.001\right) \\
& \mathrm{Y}_{\mathrm{LTW}}=36.3( \pm 8.1)^{* * *} \mathrm{X}_{\mathrm{K}}+27.4( \pm 16.0)\left(R^{2}=0.56,{ }^{* * *} \mathrm{P}<0.001\right) \\
& \mathrm{Y}_{\mathrm{DTW}}=1.51( \pm 0.36)^{* * *} \mathrm{X}_{\mathrm{CP}}+7.60( \pm 5.63) \quad\left(R^{2}=0.36,{ }^{* * *} P<0.001\right) \\
& \mathrm{Y}_{\mathrm{LTW}}=4.15( \pm 1.68)^{*} \mathrm{X}_{\mathrm{CP}}+29.4( \pm 28.1)\left(R^{2}=0.26,{ }^{*} \mathrm{P}<0.05\right)
\end{aligned}
$$

There were strong positive correlations between DMI, $\mathrm{N}$ intake, $\mathrm{K}$ intake or urine volume and TWI in dry and lactating cows (Figure 3). The regression equations of DMI $\left(\mathrm{X}_{\mathrm{DMI}}\right), \mathrm{N}$ intake $\left(\mathrm{X}_{\mathrm{NI}}\right), \mathrm{K}$ intake $\left(\mathrm{X}_{\mathrm{KI}}\right)$ and urine volume $\left(\mathrm{X}_{\mathrm{UV}}\right)$ on TWI in dry cows $\left(\mathrm{Y}_{\mathrm{DTW}}\right)$ and TWI in lactating cows $\left(\mathrm{Y}_{\mathrm{LTW}}\right)$ were as follows.

$$
\begin{aligned}
& \mathrm{Y}_{\mathrm{DTW}}=5.91( \pm .1 .30)^{* * *} \mathrm{X}_{\mathrm{DMI}}-15.2( \pm 10.1)\left(R^{2}=0.40,{ }^{* * *} P<0.001\right) \\
& \mathrm{Y}_{\mathrm{LTW}}=6.24( \pm 0.67)^{* * *} \mathrm{X}_{\mathrm{DMI}}-31.0( \pm 13.9)^{*}\left(R^{2}=0.86,{ }^{* * *} P<0.001\right) \\
& \mathrm{Y}_{\mathrm{DTW}}=0.140( \pm 0.020)^{* * *} \mathrm{X}_{\mathrm{NI}}+4.28( \pm 3.78) \quad\left(R^{2}=0.63,{ }^{* * *} P<0.001\right) \\
& \mathrm{Y}_{\mathrm{LTW}}=0.129( \pm 0.018)^{* * *} \mathrm{X}_{\mathrm{NI}}+26.4( \pm 10.3)^{*}\left(R^{2}=0.50,{ }^{* * *} P<0.001\right) \\
& \mathrm{Y}_{\mathrm{DTW}}=0.105( \pm .0 .011)^{* * *} \mathrm{X}_{\mathrm{KI}}+11.1( \pm 2.3)^{* * *}\left(R^{2}=0.74,{ }^{* * *} P<0.001\right) \\
& \mathrm{Y}_{\mathrm{LTW}}=0.141( \pm 0.015)^{* * *} \mathrm{X}_{\mathrm{K}}+40.6( \pm 6.5)^{* * *}\left(R^{2}=0.85,{ }^{* * *} P<0.001\right) \\
& \mathrm{Y}_{\mathrm{DTW}}=1.66( \pm 0.18)^{* * *} \mathrm{X}_{\mathrm{UV}}+8.98( \pm 2.45){ }^{* * *}\left(R^{2}=0.75,{ }^{* * *} P<0.001\right) \\
& \mathrm{Y}_{\mathrm{LTW}}=1.72( \pm 0.26)^{* * *} \mathrm{X}_{\mathrm{UV}}+60.6( \pm 6.0)^{* * *}\left(R^{2}=0.74, \quad{ }^{* * *} P<0.001\right)
\end{aligned}
$$

\section{DISCUSSION}

Several factors affect amounts of DWI or TWI in dairy cows, and DMI, milk yield, environmental temperatures and dietary DM, CP, Na and fiber were included in the factors (NRC, 2001). Environmental temperature and relative humidity are important factors for water intake in dairy cows (Murphy, 1992; NRC, 2001; Meyer et al., 2004; Cardot et al., 2008), and water is an especially important nutrient during heat stress. Because climatic condition was controlled at $20^{\circ} \mathrm{C}$ and $60 \%$ relative humidity in this study, data obtained may be not affected by environmental temperature and humidity. 
DMI and milk production were highly related to DWI and TWI of lactating cows in this study. Milk production is closely correlated to DMI or water intake (Murphy, 1992; Kramer et al., 2008). With 33-35 kg/day of milk production, DWI and TWI per kg of milk produced were 2.0-2.7 and 2.6-3.0 kg, respectively, but those with lower milk production, less than 26kg/day, were 2.6-3.0 and 3.3-4.2 kg, respectively (NRC, 2001). In this study, increasing milk yield increased DWI and TWI in lactating cows, and mean DWI and TWI per kg of milk produced in cows were 2.6 and $3.3 \mathrm{~kg}$, respectively. According to $29.5 \mathrm{~kg}$ of averaged milk yield in this study, these figures were considered to be appropriate, compared to the data in NRC (2001). In dry cows, increasing DMI increased TWI, but DWI was not affected by increasing DMI, which suggested that feed water was a predominant water source for dry cows fed silages and FWI influenced DWI.

Dietary DM content is one of the major factors affecting DWI in dairy cows (NRC, 2001). Increasing DM percentage of the diet increased DWI in dairy cows but decreased TWI (Paquay, et al., 1970; Murphy, 1992; Dahlborn, et al., 1998; Dewhurst et al. 1998), which indicated that the increased DWI was not able to compensate for the reduction of FWI. TWI in lactating cows were not affected by increasing dietary DM, but DWI in dry cows increased about 7L/day and TWI decreased about 15L/day as ration moisture dropped from 70 to $40 \%$ (Holter and Urban 1992). In this study, DWI in dry and lactating cows increased and FWI decreased as dietary DM increased, but clear relationships between dietary DM and TWI were not obtained in dry and lactating cows.

TWI and FWI in dry cows increased as dietary ADF increased in this study, but negative correlation were obtained between dietary NDF and TWI or DWI in lactating cows. Increasing ADF or NDF intake increased TWI and FWI in dry cows, and increasing ADF intake increased TWI and DWI in lactating cows. Because increasing forage in the diet might increase water requirements by increasing water loss in feces and urine (Dahlborn, et al., 
1998; NRC, 2001) and high NDF diet might decrease TWI in lactating cows (Dado and Allen, 1995), dietary ADF or NDF may be a factor affecting TWI in dairy cows fed silages.

In both dry and lactating cows in this study, significant correlations were obtained between dietary CP or K and TWI, especially highly correlations between dietary K and TWI. Dietary K was correlated to DWI in dry and lactating cows, and dietary CP is correlated to DWI in dry cows. Also, $\mathrm{N}$ intake, $\mathrm{K}$ intake or urine volume in dry and lactating cows were more related to TWI rather than DWI, and the increasing rates of $\mathrm{N}$ intake, $\mathrm{K}$ intake and urine volume on TWI were almost similar between dry and lactating cows. These results suggest that dry and lactating cows accelerate DWI to excrete large amounts of $\mathrm{K}$ or $\mathrm{N}$ into urine in excess of their needs, but TWI is more suitable to evaluate the effects of dietary CP or K on water intake and urine volume in dairy cows.

Delaquis and Block (1995) reported that apparent absorption of water and urine volume in dairy cows was increased by a higher dietary cation-anion difference defined as milliequivalents of (Na+K-Cl-S)/kg of DM. Bannink et al. (1999) suggested that urine volume is determined mainly by the effect of $\mathrm{Na}, \mathrm{K}$ and $\mathrm{N}$ on urine osmolality. In the previous paper (Kume et al., 2008a), the urine volume in cows was affected by the wide range of water intake and increased as urinary $\mathrm{K}$ or $\mathrm{N}$ excretion increased, but urine volume was not affected by urinary Na excretion. The diets high in protein appear to stimulate water intake of cows, and then water excess reduced the osmolality of extracellular fluid, resulting in water diuresis and normalization of plasma osmolality (Kohn et al., 2005; Kume et al., 2008a, 2008b). In adjusting the urine osmolality in cows, $\mathrm{K}$ played an important role in the formation of concentrated urine at low urinary $\mathrm{K}$ excretion, but the concentrating capacity of $\mathrm{K}$ at high urinary excretion was almost constant due to the isotonic function of the tubule and the increasing urinary flow in the collecting duct of kidney due to the increase of water intake may be needed to excrete larger quantities of K (Kume et al., 2008a). Paquay et al. (1970) 
reported that the increase in urinary water loss for dry and lactating cows, especially if the result of given food with a high moisture content, is related to a greater excretion of $\mathrm{N}$ and $\mathrm{K}$ in urine. Because of maintenance of plasma or urine osmolality, dietary $\mathrm{N}$ and $\mathrm{K}$ may have large effects on water intake and urine volume in dry and lactating cows fed silages.

In practical dairy farming, cows fed alfalfa silage produced more milk than did cows fed grass silage (Hoffman et al., 1998 ; Kume, 2002), but alfalfa with 20\% of CP contained high K such as $3.49 \%$ in the first cutting (Kume et al., 2001). Corn silage contained 7.1 to $8.2 \%$ of $\mathrm{CP}$ and 1.2 to $1.3 \%$ of $\mathrm{K}$, and feeding corn silage decreased urinary $\mathrm{N}$ and $\mathrm{K}$ excretion in cows (Kume et al., 2003, 2008a, 2008b). Also, feeding corn silage plus alfalfa silage derived maximal benefit and 5 to $15 \%$ reduction in the loss of $\mathrm{N}$ to the environment (Dhiman and Satter, 1997). However, the increased K intake in dry cows may raise urine volume and thereby result in increased urinary $\mathrm{N}$ excretion according to the path analysis (Kojima et al. 2005), and $5 \%$ of $\mathrm{KCl}$ supplementation increased urinary $\mathrm{N}$ excretion as well as .water intake and urine volume in mice (Murai et al. 2008, in press). Further study is needed to clarify the relationships between water intake, nutrient intake and urine production for cows in the dairy farms to eliminate environmental pollution and obtain maximal benefit.

\section{ACKNOWLEDGMENTS}

The authors thank S. Naito, S.Nakajima and the staff of the National Agricultural Research Center for Hokkaido Region for technical help and assistance of sample collection.

\section{REFERENCES}

Agriculture, Forestry, and Fisheries Research Council Secretariat, 1994. Japanese Feeding Standard for Dairy Cattle. p19-24. Chuouchikusankai. Tokyo. Japan.

Bannink, A., Valk,A., Van Vuuren, A.M. 1999. Intake and excretion of sodium, potassium, 
and nitrogen and the effects on urine production by lactating dairy cows. J.Dairy Sci. 82, 1008-1018.

Cardot, V., Le Roux, Y., Jurjanz. 2008. Drinking behavior of lactating dairy cows and prediction of their water intake. J. Dairy Sci. 91, 2257-2264.

Dadd, R.G., Allen, M.S. 1995. Intake limitations, feeding behavior, and rumen function of cows challenged with rumen fill from dietary fiber or inert bulk. J. Dairy Sci. 78, 118-133.

Dahlborn, K., Akerlind, M., Gustafson, G. 1998. Water intake by dairy cows selected for high or low milk-fat percentage when fed two forage to concentrate ratios with hay or silage. Swedish J. agric. Res. 28, 167-176.

Dewhurst, R.J., Offer, N.W., Thomas, C. 1998. Factors affecting water intake of lactating dairy cows offered grass silages differing in fermentation and intake characteristics. 1998. Animal Science. 66, 543-550.

Delaquis, A.M., Block, E. 1995. Dietary cation-anion difference, acid-base status, mineral metabolism, renal function, and milk production of lactating cows. J.Dairy Sci. 78, 2259-2284.

Dhiman, T.R., Satter, L.D. 1997. Yield response of dairy cows fed different proportions alfalfa silage and corn silage. J.Dairy Sci. 80, 2069-2082.

Hoffman, P.C., Combs,D.K., Casler, M.D., 1998. Performance of lactating dairy cows fed alfalfa silage or perennial ryegrass silage. J.Dairy Sci. 81, 162-168.

Holter, J.B., Urban, Jr, W.E. 1992. Water partitioning and intake prediction of dry and lactating Holstein cows. J.Dairy Sci. 75, 1472-1479.

Kohn, R.A., .Dinneen,M. Russek-Cohen. 2005. Using blood urea nitrogen to predict nitrogen excretion and efficiency of nitrogen utilization in cattle, sheep, goats, horses, pigs, and rats. J.Anim.Sci. 83, 879-889. 
Kramer, E., Stamer, E., Mahlkow, K., Lüpping, W., Krieter, J. 2008. Relationships between water intake, dry matter intake and daily milk yield on a German research farm. Livest. Sci. 115, 99-104.

Kume, S. 2002. Establishment of profitable dairy farming system on control of methane production in Hokkaido region, In:Takahashi,J. and Young,B.A.(eds) , Greenhouse Gases and Animal Agriculture, 87-94. Elsevier Science B.V.

Kume, S., Nonaka, K., Oshita,T., Kozakai, T, Hirooka, H. 2008a. Effects of urinary excretion of nitrogen, potassium and sodium on urine volume in dairy cows. Livest. Sci. 115, 28-33.

Kume, S., Nonaka, K., Oshita,T., Kozakai, T, Kojima,H. 2004. Potassium excretion of dry, pregnant and lactating cows fed forage. Nihon Chikusan Gakkaiho 75, 179-184 (In Japanese, with English abstract).

Kume,S., Toharmat,T., Nonaka,K., Oshita,T., Nakui,T., Ternouth, J.H.. 2001. Relationships between crude protein and mineral concentrations in alfalfa and value of alfalfa silage as a mineral source for periparturient cows. Anim. Feed Sci. Tech. 93, 157-168.

Kume, S., Numata, K., Takeya, Y., Miyagawa, Y., Ikeda, S., Kitagawa, M, Nonaka, K, Oshita, T, Kozakai, T. 2008b. Evaluation of urinary nitrogen excretion from plasma urea nitrogen in dry and lactating cows. Asian-Aust. J. Anim. Sci. 21, 1159-1163.

Kojima, H., Kume,S., Nonaka,K., Oshita,T., Kozakai,T., Hirooka,H. 2005. Effects of feeding and animal performance on nitrogen, phosphorus and potassium excretion by Holstein cows. Anim. Sci. J. 76, 139-145.

Meyer, U., Everinghoff, M., Gädeken, D., Flachowsky, G.. 2004. Investigation on the water intake of lactating dairy cows. Livest. Prod. Sci. 90, 117-121.

Murai I, Imanishi S, Sugimoto M, Kume S. 2008. Effects of high potassium chloride supplementation on growth rate and renal function in mice. Anim. Sci. J. 79, 243-247. 
272 Murai I, Sugimoto M, Ikeda, S., Kume S. Effects of high potassium chloride supplementation

273

274 on water intake, urine volume and nitrogen balance in mice. Anim. Sci. J. (in press)

Murphy, M.R., 1992. Water metabolism of dairy cattle. J.Dairy Sci. 75, 326-333.

National Research Council, 2001. Nutrient requirements of dairy cattle. 7th. rev. ed. Natl.Acad.Sci., Washington,D.C.

Paquay, R., De Bafre, R., Lousse, A. 1970. Statistical research on the fate of water in the adult cow. II . The lactating cows. J. Agric. Sci. (Camb.). 75, 251-255.

Statistical Analysis System (SAS). 1997. SAS/STAT Software: Changes and Enhancement Through Release 6.12. SAS Institute, Cary, NC.

Steiger Burgos, M., Senn, M., Sutter, F., Kreuzer, M., Langhans, W. 2001. Effect of water restriction on feeding and metabolism in dairy cows. Am. J. Physiol. Regulatory Integrative Comp. Physiol. 280, R418-R427. 
Table 1.

Correlation between total water intake (TWI) ${ }^{1}$, drinking water intake (DWI), feed water intake (FWI) and other variables in dry cows $(n=30)$

Mean SD Min. Max. TWI $\quad$ DWI FWI

Nutrient, \% of DM

$\begin{array}{lrrrrlll}\text { DM } & 38.1 & 11.0 & 21.6 & 58.1 & 0.40 * & 0.82 * * * & -0.89 * * * \\ \text { CP } & 15.0 & 3.8 & 10.6 & 22.4 & 0.62 * * * & 0.54 * * & -0.11 \\ \text { ADF } & 33.6 & 5.6 & 21.3 & 41.8 & 0.60 * * * & 0.22 & 0.42 * \\ \text { NDF } & 46.7 & 7.2 & 34.0 & 63.3 & 0.23 & -0.11 & 0.49 * * \\ \text { K } & 2.35 & 0.93 & 1.07 & 4.04 & 0.74 * * * & 0.79 * * * & -0.39 *\end{array}$

Intake

DM, kg/day

$7.7 \quad 1.0 \quad 6.1$

9.7

$0.65 * * * \quad 0.29$

0.36

$\mathrm{N}, \mathrm{g} /$ day

186

54

109

$0.80 * * * \quad 0.54 * *$

0.13

ADF, kg/day

2.62

0.67

1.55

3.78

$0.70 * * * \quad 0.26$

$0.47 * *$

NDF, kg/day

$3.64 \quad 0.92$

2.29

5.78

$0.49 * * \quad 0.09$

$0.49 * *$

$\mathrm{K}$, g/day

$183 \quad 77$

81

$0.87 * *$

$-0.24$

Body weight, $\mathrm{kg}$

$619 \quad 66$

$515 \quad 803$

0.13

$-0.05$

$0.46 * *$

Urine volume, kg/day

12.8

4.9

$6.7 \quad 24.0$

$0.87 * * * \quad 0.81 * * *-0.25$

Fecal water, kg/day

12.4

3.1

$6.4 \quad 18.5$

$0.64 * * * \quad 0.31$

0.32

TWI, kg/day

30.3

9.3

14.6

DWI, kg/day

16.0

12.2

0.3

48.1

FWI, kg/day

14.3

7.1

5.3

39.5

$--$

${ }^{*} \mathrm{P}<0.05$.

${ }^{* *} \mathrm{P}<0.01$.

${ }^{* * *} \mathrm{P}<0.001$

${ }^{1}$ Drinking water intake plus feed water intake. 
Table 2.

Correlation between total water intake (TWI) ${ }^{1}$, drinking water intake (DWI), feed water intake (FWI) and other variables in lactating cows $(n=16)$

\section{Nutrient, \% of DM}

\begin{abstract}
DM
\end{abstract}
$\mathrm{CP}$

ADF

NDF

$\mathrm{K}$

Intake

$$
\text { DM, kg/day }
$$

$\mathrm{N}$, g/day

\begin{abstract}
ADF, kg/day
\end{abstract}
NDF, kg/day

$\mathrm{K}$, g/day

Body weight, kg

Milk yield, kg/day

Urine volume, kg/day

Fecal water, kg/day

TWI, kg/day

DWI, kg/day

FWI, kg/day

$51.2 \quad 9.5$

$16.6 \quad 2.0$

38.2

64.7

12.3

26.4

1.9

39.4

1.96

6.3

24.5

18.3

$0.52 *$

$0.83^{* * *}-0.93^{* * *}$

$6.3 \quad 31.8$

$32.5-0.26$

0.37

0.21

$0.32 \quad 1.56$

48.4

$-0.69 * *$

$-0.22$

0.00

2.31

$0.77 * * * \quad 0.55 *$

$-0.11$

0.19

$20.7 \quad 2.2 \quad 17.2 \quad 24.1 \quad 0.93 * * * \quad 0.83 * * *-0.16$

$\begin{array}{lllllll}557 & 102 & 387 & 705 & 0.89 * * * & 0.73 * * & 0.01\end{array}$

$\begin{array}{lllllll}5.45 & 0.63 & 4.22 & 6.19 & 0.68 * * & 0.63 * * & -0.14\end{array}$

$8.10 \quad 1.16$

6.48

10.27

$-0.11$

$-0.01$

$410 \quad 98$

$609 \quad 48$

268

555

$0.93^{* * *}$

$0.75 * * *-0.02$

$29.5 \quad 3.5$

$21.9 \quad 7.5$

557

703

0.05

0.03

0.03

21.9

21.9

35.3

$0.66^{* *}$

$0.62 * *$

$-0.18$

35.2

7.2

11.2

33.2

$0.87 * * *$

$0.73 * *-0.02$

98.4

14.9

22.4

45.4

0.28

0.16

0.15

77.6

18.1

78.1

124.2

20.8

57.0110 .3

$--$

$\begin{array}{lll}12.0 & 36.4 & -0.20\end{array}$

\footnotetext{
${ }^{*} \mathrm{P}<0.05$.

${ }^{* *} \mathrm{P}<0.01$.

${ }^{* * *} \mathrm{P}<0.001$
}

${ }^{1}$ Drinking water intake plus feed water intake. 
Figure 1. Relationships between dietary DM contents and total water intake (०), drinking water intake $(\bullet)$ or feed water intake $(\boldsymbol{\Delta})$ in dry and lactating cows.

Figure 2. Relationships between dietary $\mathrm{CP}$ or $\mathrm{K}$ contents and total water intake (०) or drinking water intake $(\bullet)$ in dry and lactating cows.

Figure 3. Relationships between DMI, Urine volume, CP or K intake and total water intake (०) or drinking water intake ( ) i n dry cows and relationships between DMI, urine volume, CP or K intake and total water intake ( $\square$ ) or drinking water intake (घ) in lactating cows. 


\section{Lactating cows}
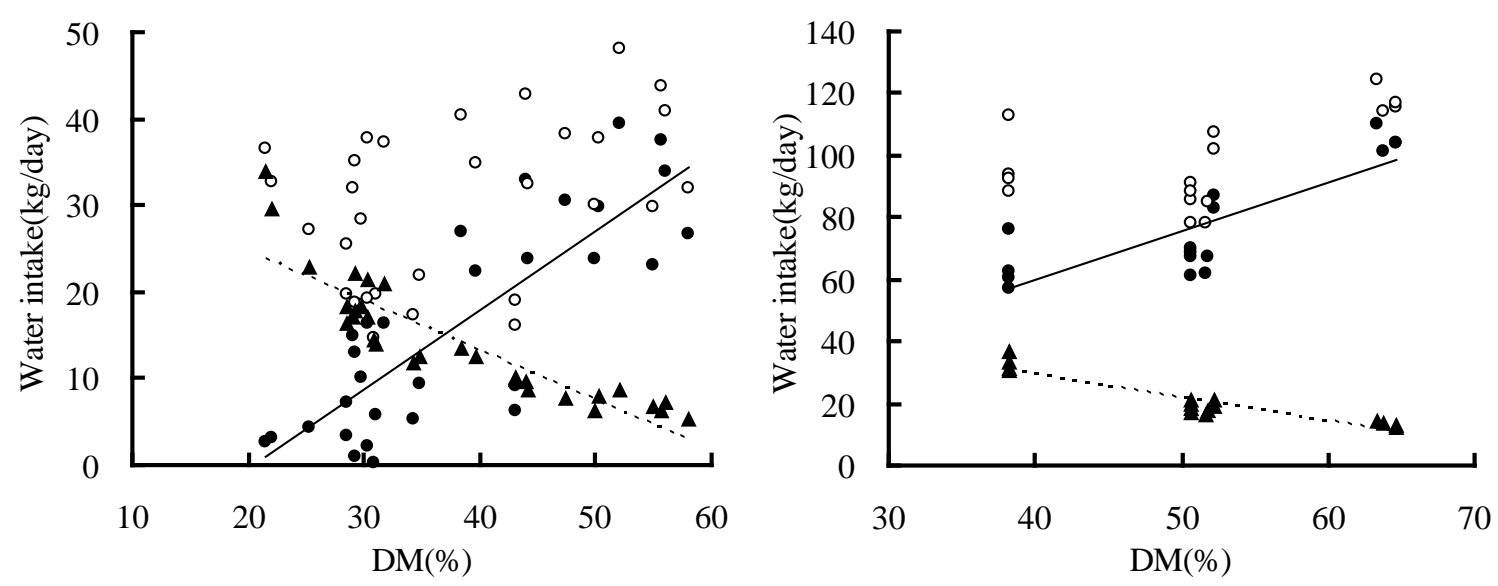

Fig.1 

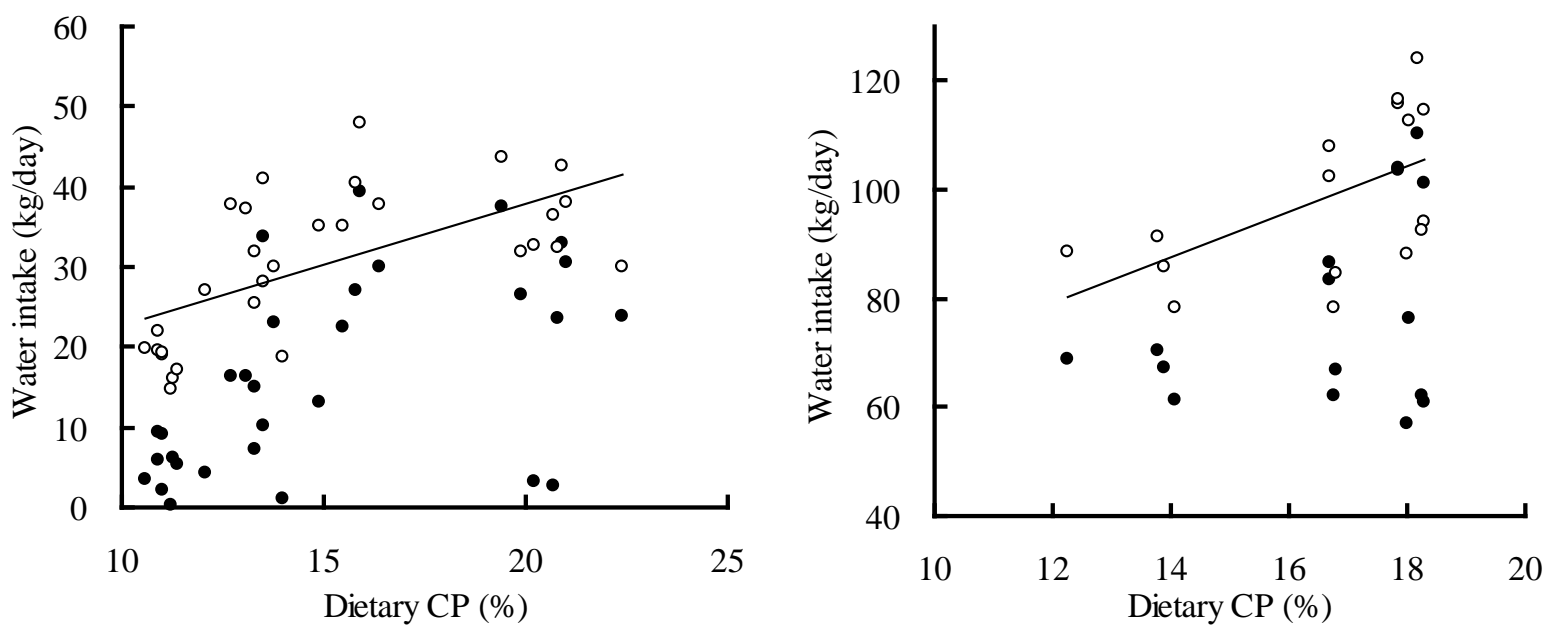

31
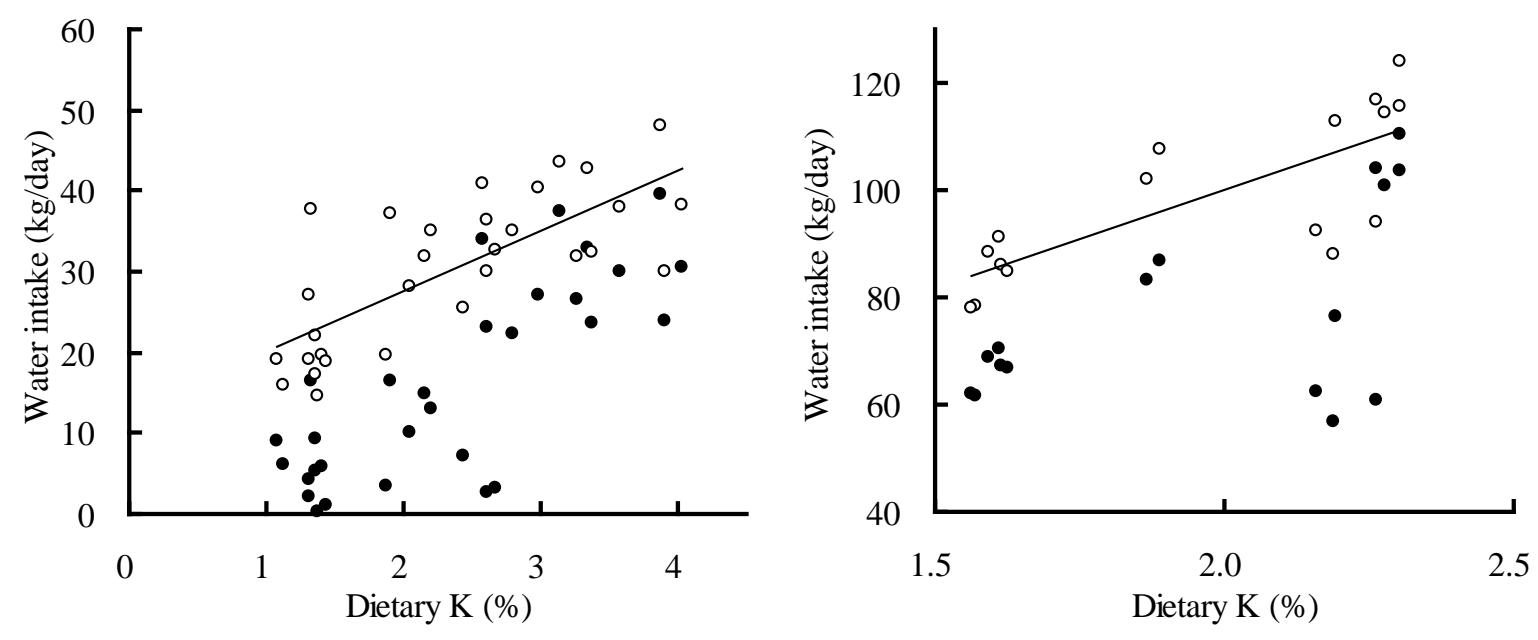

Fig.2 

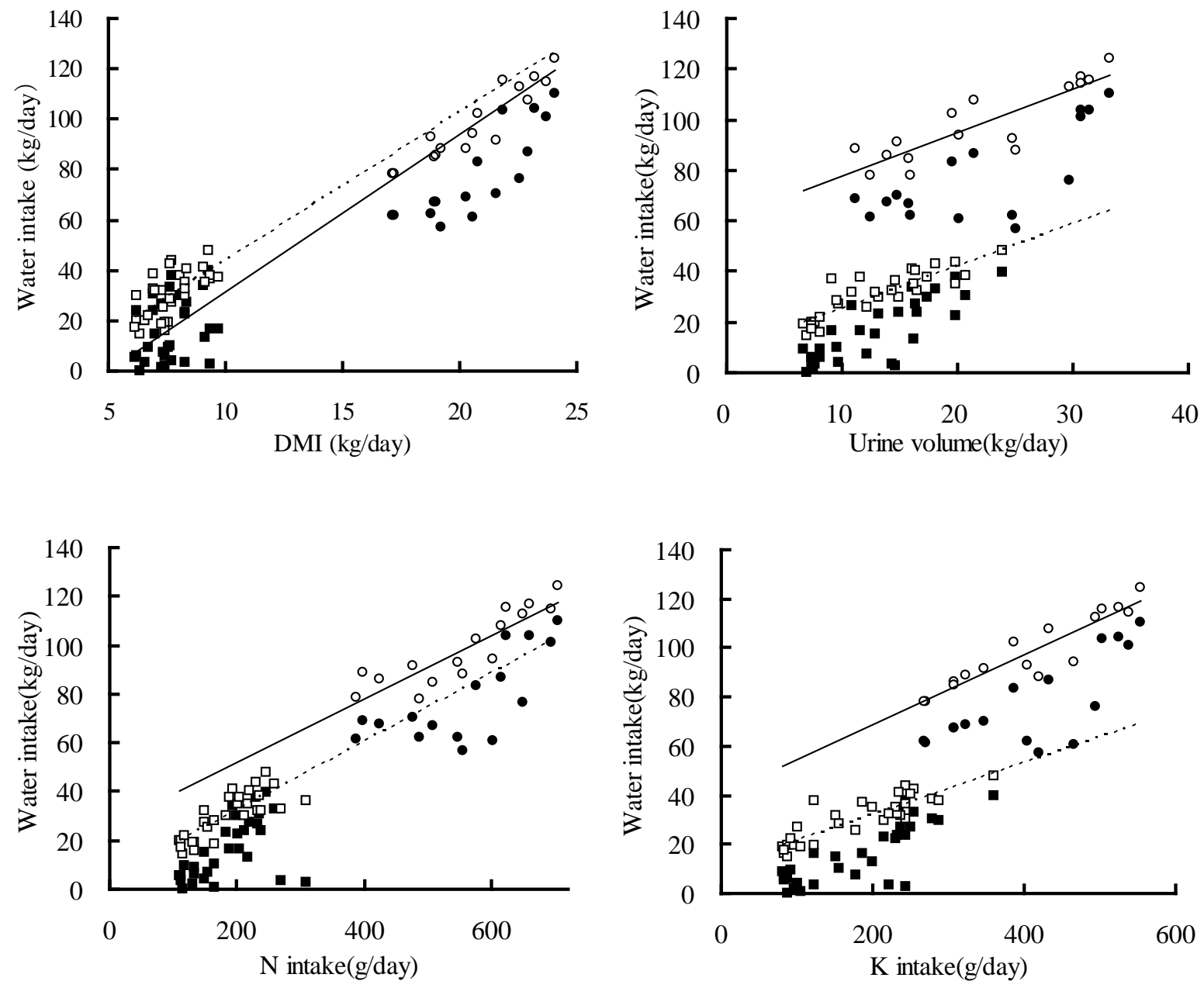

Fig.3 